\title{
Development of Product Design Projects Applying Specifications and Factors Matrix (SFM) as a Support Tool in Higher Education
}

\author{
José Luis Santolaya, Anna Maria Biedermann, Ana Serrano \\ Design and Manufacturing Engineering Department, EINA, University of Zaragoza, Zaragoza, Spain \\ Email: jlsanto@unizar.es
}

Received 9 March 2016; accepted 26 April 2016; published 29 April 2016

Copyright $(\subset 2016$ by authors and Scientific Research Publishing Inc.

This work is licensed under the Creative Commons Attribution International License (CC BY).

http://creativecommons.org/licenses/by/4.0/

(c) (i) Open Access

\begin{abstract}
The application of work strategies taking into account, from the initial stages, all the factors involved in the product design process is considered essential by the researches to generate higher quality products, assess users' needs and anticipate design problems. This paper presents two approaches of design project development, denominated respectively: projects with imposed specifications and projects with derived specifications and proposes the use of the matrix that integrates specifications and design factors (SFM). This design support tool complements others already used in the development of product concepts by higher education students, increasing the capacity of synthesis and structuring of information in order to facilitate decision-making into the design process. Its elaboration implies understanding of objectives, identifying of factors and establishing of specifications. At the same time, it aims to foster the reflection process and an integrated information analysis. The application of SFM and its contribution to different project approaches are shown in this paper.
\end{abstract}

\section{Keywords}

Product Design, Matrix, Specifications, Factors, Engineering Education

\section{Introduction}

A large number of tasks and activities, arranged in a logical order, are involved in the design process of a product, in order to get the best result with minimal effort [1] [2]. The perception of an unsatisfied necessity or a market opportunity is the starting point to achieve the commercialization and final use of a product [3]. The main stages that are part of the product design process are presented in Figure 1. New needs, improvements or 
innovation opportunities can be detected throughout the process, giving rise to the definition of a new design concepts or the transformation of the existing ones.

In an increasingly significant way, designers experience the benefit of investigation throughout all stages of design process. In order to achieve competitive and high quality products Barba [4] and Patrick [5] suggest that it is necessary to apply working methods that analyse, from the early stages, all the factors involved in this process. As Maldonado [6] proposes, the design of an object is the result of the integration of various types of factors: functional, cultural, technological or economical. Thus, product design must not only consider the users' needs, but should also pay attention to the conditions set by the manufacturers, to the governmental regulations and the social and cultural environment. Recent works being carried out in engineering design show how the number of factors that are under investigation is increasing [7] [8].

Different methodological proposals related to the development of the design activity can be found in the literature [9]-[11]. The product design engineering provides students a great number of techniques and design support tools facilitating tasks such as the planning, drawing users wishes and needs, information search, approach to problems and possible solutions, as well as to provide ideas about how and when to deploy them effectively. A complete review of these tools can be found in Ramirez [12] and Milton and Rodgers [13].

Moreover, a series of competencies should be acquired by the students to define and structure design problems and achieve its resolution [14] [15]. Among them, the ability to organize and to plan, to analyse and synthesize, creativity, communication skills and information management can be highlighted, not to mention the ability to combine the approaches of various areas of knowledge [16]. The tools attending the design also support and reinforce the performance of these skills by novel designers. However, the need to reinforce the reflection and synthesizing processes in the academic curricula related to product engineering has been observed [17]-[19]. Different experiences based on the planning and development of the process have been carried out in order to improve the definition of design problems, enhance the interconnectivity and strengthen the synthesis process [20] [21].

This paper focuses at the early stages of the product design, because it is into them where values of differentiation and quality are being established. That is why it shows two different approaches to design projects identified during their implementation. A specific tool based on a matrix, to effectively synthesize and organize the initial project information is proposed. In particular, it is used to relate specifications and design factors, establishing a framework from which it is possible to generate and analyse viable design alternatives.

As indicated by Bjornfot and Stehn [22], matrices are tools suitable to illustrate the interactions between various elements. Such tools can be included within the techniques referred as Dependency and Structure Modelling or DSM, which take advantage of their ability to relate and structure information to manage complexity [23]. To show its usefulness they have been applied in several case studies related to the design of different types of product.

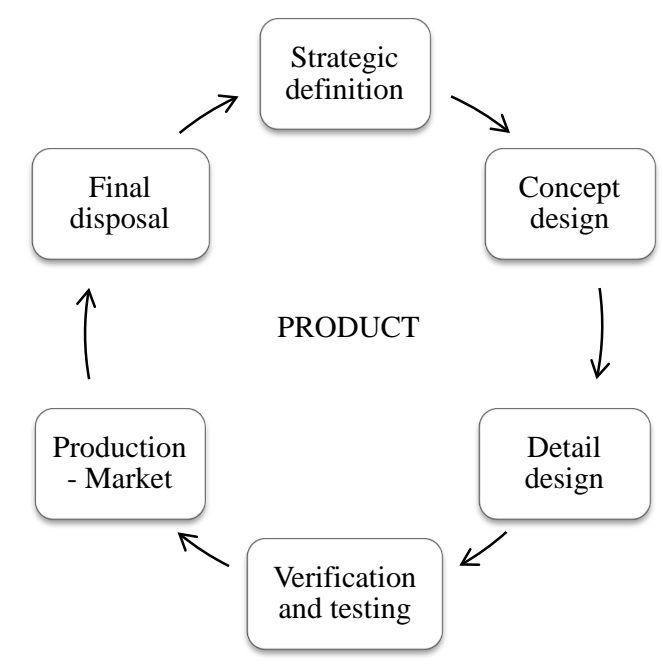

Figure 1. Stages of product design process. 


\section{Approach to Design Projects}

The project methodology involves developing activities in a sequential and repeatable way with the idea of achieving the desired result. Applied to the design and development of the product it comprises the transformation of conditions, needs and requirements into a concept or idea able to satisfy them [24] [25]. The early stages of the design process contain a high level of conceptualization and confer on the design engineering a remarkable complexity.

The main objective of the strategic definition stage (Figure 2) is to identify a problem, a need or an opportunity for the product improvement.

A series of actions are carried out in order to determine the requirements of the new product and the work plan for its definition and development. At this stage multiple tools are being used and different competencies are required. In addition, the detailed investigation of the legislation and the industrial property related to the product is needed, as well as the determination of the factors regarding the sustainability of the process.

The concept design stage is characterized by the use of the conclusions reached at the previous step (Figure 3). Ideas that provide solutions to the identified problems are being generated and different design alternatives or product concepts are being proposed for the selection of the most appropriate ones.

Figure 3 shows a series of actions that are carried out at this stage, assisted by different tools. Given that there are multiple factors involved, working with a multidisciplinary team will favour the decision making process.

Considering these early stages of the design process, a product design project can be developed according to one of these approaches:

1) The product must meet initial specifications defined usually with a remarkable degree of concreteness. The main objective of the project is to propose product concepts that respond to these requirements.

2) The product specifications are not set a priori, but are obtained from both the analysis of design factors (critical or general specifications) and the generated concepts (desired or particular specifications).

These two approaches have been called respectively: 1) imposed specifications and 2) derived specifications. The tasks involved in the early stages of a design project with specifications imposed are shown in Figure 4. The starting point lies in the definition of design specifications, which are set by the client and are communicated to the designer. The following step is to perform the identification of design factors and to develop a matrix that allows organizing and relating specifications and factors. The matrix can be used for the concept generation analysing the initial project information. The final task is the concept selection and detail design development. If the approach to the design project is carried out with derived specifications, the initial sequence of tasks is the one shown in Figure 5. This strategy is applied usually when the client wants to introduce a new product, or to expand the range of products, and leaves its definition to the designer. In this case, the initial task is to identify design factors. After its study and review, design specifications called critical or general are defined, as they are needed in the development of any new proposal. This information is synthesized and organized using a matrix.

Then, concepts that constitute an improvement, transformation or innovation in any of the factors involved in the design are proposed. The prior application of the appropriate methods of factors identification favours the generation of innovative product concepts [26]. For each concept or idea, the product specifications, called desired or particular, are defined. These specifications allow the differentiation over the existing products and complete the previously created matrix. Finally, the selection and development of one of the concepts is performed.

In both approaches, a matrix that combines specifications and factors is created (SFM) and for its elaboration, it is proposed to group specifications and factors into three main blocks:

- Operation and function. The products seek to satisfy a need, to perform a function or even to meet multiple functions, ordered usually with a priority order [27]. This operational capacity must be achieved through a system or set of elements, which interact with each other and make it in a coordinated manner.

- User and environment. Since it is the people who use goods and services, one of the key elements of the design is its adaptation to people and their needs. Some methodologies put user at the centre of all processes, as it is him experiencing the sensations and emotions that the attributes of a product or service cause [28].

- Production process. The possibility that the product reaches the user depends on manufacture viability. A series of design techniques have been implemented in the production process throughout the last decades [29] [30]. These techniques called DFX, aim to achieve the optimization of various aspects such as materials logistics, manufacturing, assembly, inspection, distribution, maintenance, etc. 

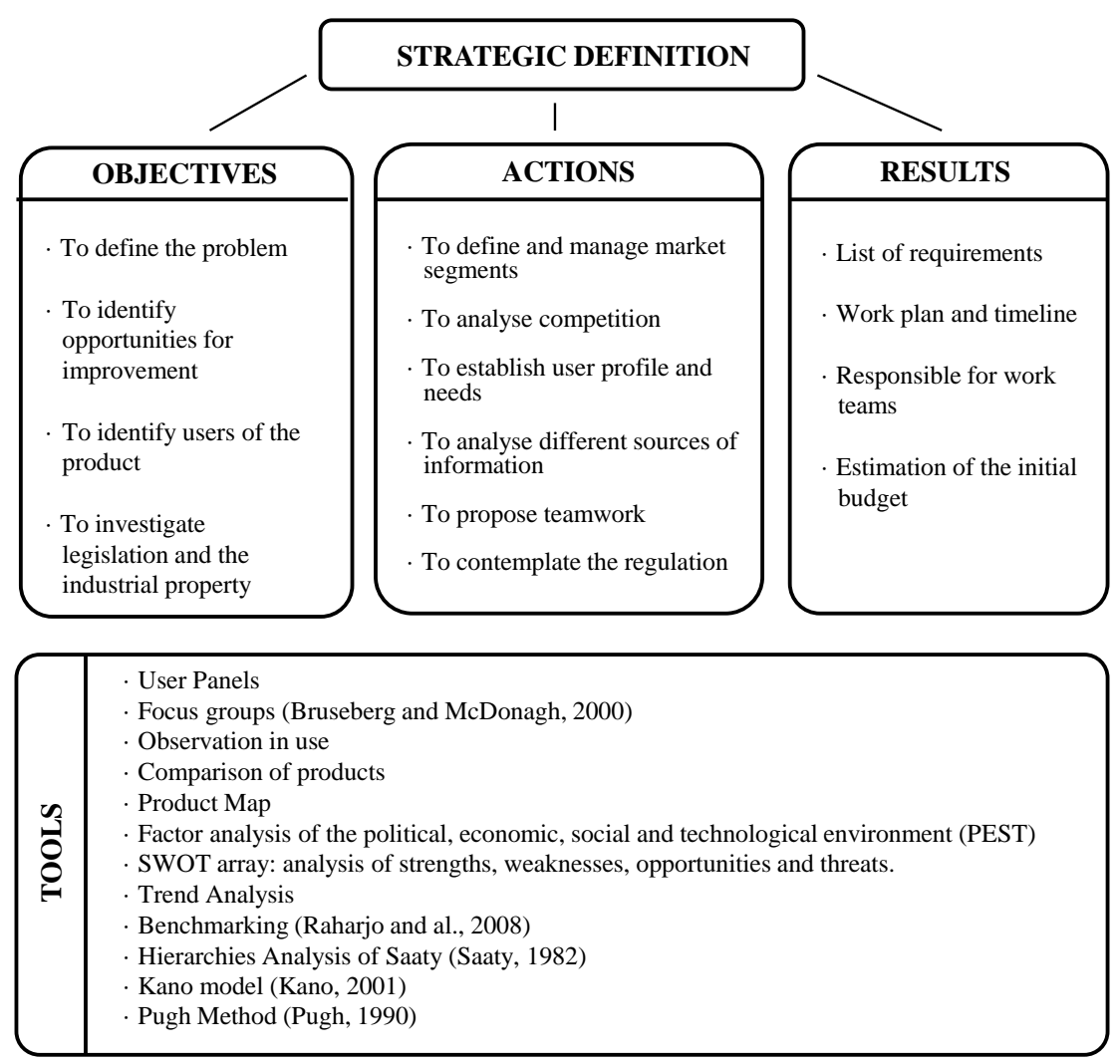

Figure 2. Strategic definition stage in the product design process.
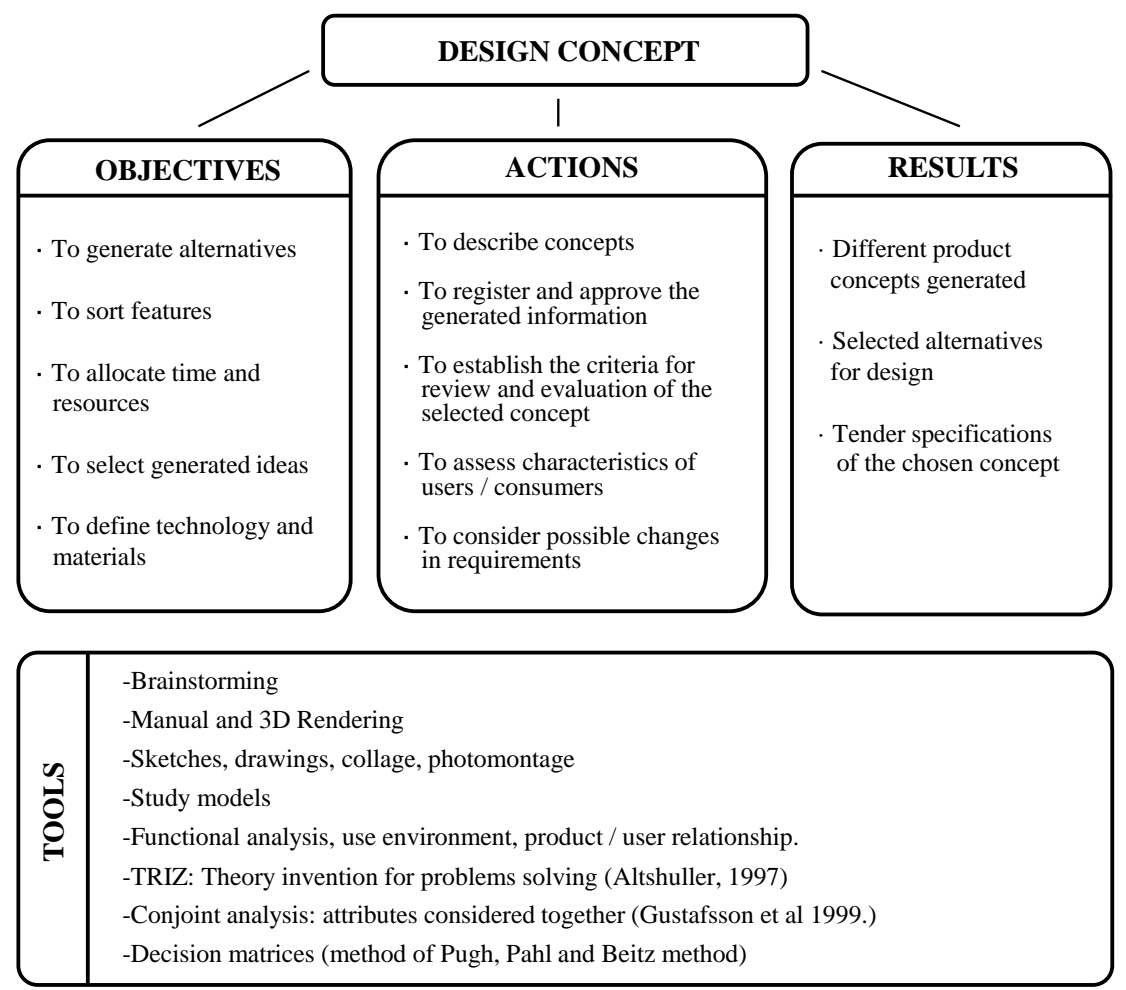

Figure 3. Design concept stage in the product design process. 


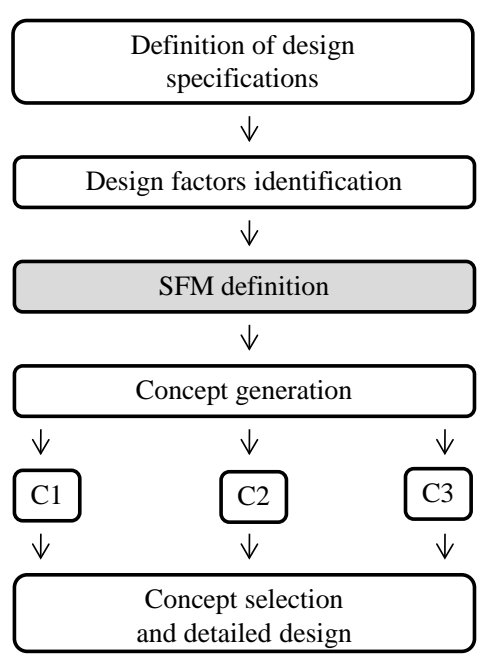

Figure 4. Approach of a product design project with imposed specifications.

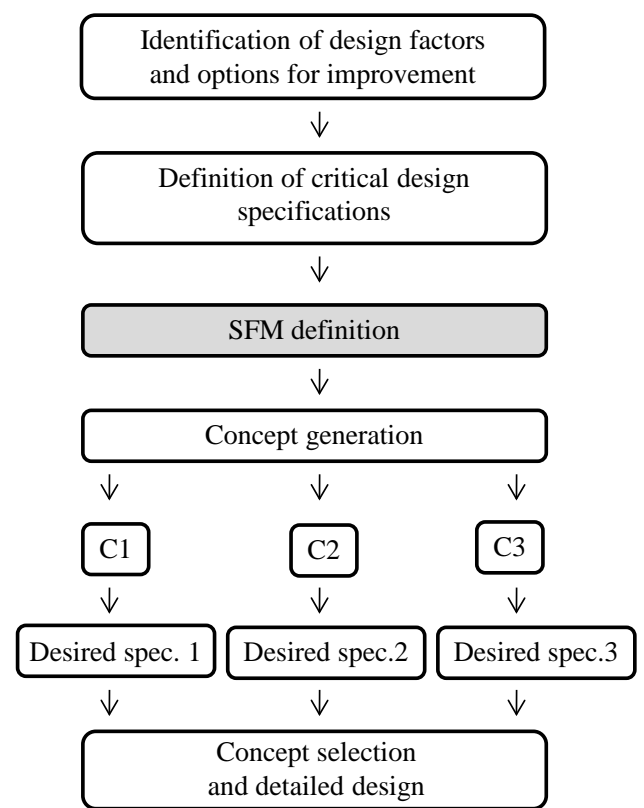

Figure 5. Approach of a product design project with derived specifications.

To exemplify the different approach to design projects, several case studies are presented in the following section. The resulting specifications and factors matrices (SFM) are shown for each case.

\section{Case Studies}

\section{Approach 1: Projects with imposed specifications}

Two product design projects developed with known initial specifications are presented first. They have been designated as case 1: Crane for people with reduced mobility and case 2: Airbrush for high precision works.

Case 1: Crane for people with reduced mobility

The design of these types of cranes has to be adapted to the needs of users with very limited mobility and an environment that generally makes it difficult to manoeuvre. Given that they are based on a structure that supports the efforts generated according to ISO 10535:2006, in this case, it is intended to project a crane with the capacity to lift and move people along small distances and with the option to change its size to pass through narrow areas. 
The following initial design specifications were established:

- Individual use, with maximum load capacity of $180 \mathrm{~kg}$ and range of $1 \mathrm{~m}$.

- Assisted, comfortable and safe vertical movement.

- Horizontal movement not necessarily assisted.

- Drive systems without network connections.

- Adaptation to narrow passageways such as doors or hallways.

- Technical development feasible at a competitive cost.

According to the scheme of tasks shown in Figure 4, the factors involved in the crane design were identified and information driven from the analysis was summarized in a matrix (Table 1). The design specifications take the header of the rows and the factors organized by blocks of columns complete the matrix.

The user and environment block has been divided into three subgroups: mode of use, related accessories and environmental characteristics. Factors included in the mode of use are those related to the interaction between the crane and the person who manipulates it and between the crane and the individual to be transported. It therefore includes the study of the size and characteristics of the human body, the arrangement of the weight, the manner of implementing and controlling the vertical and horizontal movements and the procedure to change the range of the crane.

The dependency relations between specifications and factors have been taken into account during the development of the matrix. In this way, to propose design concepts that meet each of the initial specifications involves the detailed study of a number of factors.

As shown in Table 1, the first specification: the maximum load $180 \mathrm{~kg}$, requires a detailed study of the following factors: mechanical strength and the basic structure of the device, the provision of weight and the accessories used to make the catch; and the characteristics and availability of materials and processes used to manufacture and assembly of the crane components. Meanwhile, the specification: adaptation to narrow passages, involves the study of systems that permit to adjust the amplitude of the crane, the way to include it in the set-crane, the components of the mechanism and method of manoeuvre. Also, it is necessary the definition of the minimum amplitude of the aisles or walkways where it will be used.

Thus, the matrix in Table 1 shows the connections between factors and specifications in an organized way and synthesizes the information relating to the project in order to propose a concept of crane able to meet the initial specifications.

Case 2: Airbrush for high precision works

These devices require an airstream moving at high speed to atomize paint into fine droplets and to project it over a surface. Therefore, the user must be able to control two separate flows, air and paint, and simultaneously handle the airbrush in different applications. A custom-fitted airbrush allowing independent control of flows and precision work is projected in this case.

According to the scheme presented in Figure 4, the first task of the project was to define the design specifications. These were grouped and can be located in the header of each of the rows of a matrix (Table 2).

The previously established specifications and the research process done on the operation of this device, its interaction with the user and processes used in its manufacture was the starting point for the identification of the design factors, which was the following task. The factors, organized into columns are shown in Table 2. The user and environment block includes the different techniques of airbrushing, the way to hold and handle it in each case and the accessories and complements used to perform the works, as factors of the study. The methods used to achieve greater firmness and work precision, as well as the characteristics of the paints and the cleaning techniques are important factors to research.

A number of factors will condition the compliance with each of the specifications. E.g. the specification: different spray effects, requires the analysis of the paint projection methods, the type and characteristics of the nozzles to be used and the spray requirements of each airbrushing technique. Also, templates and supplements that are used in each case, the droplet sizes generated with the different paints and the final accuracy and quality of the components of the airbrush that can be obtained through the manufacturing systems.

In turn, the specification: adaptation to user, requires the study of the body and the handle of the airbrush, hand dimensions and holding method, accessories such as hoses and connectors next to the handle, and the characteristics of different materials especially those used in moulding.

The SFM created in two case studies presented, gather and organize the relevant information at the beginning of each project, and relate specifications and factors to favour better designs generation. 
Table 1. SFM of the design project of a crane to assist people with disabilities.

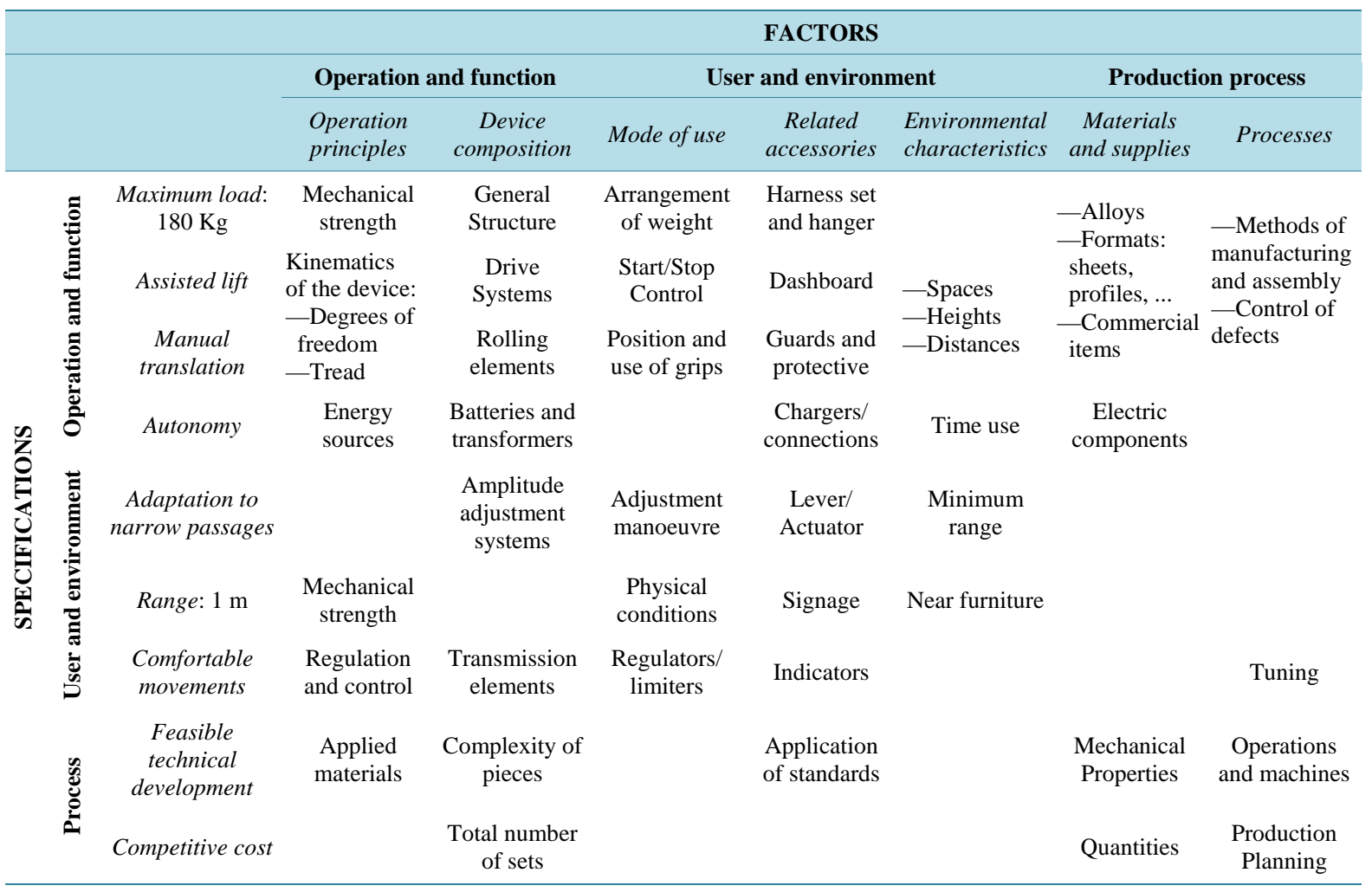

Table 2. SFM of the project design of an airbrush for high precision works.

\begin{tabular}{|c|c|c|c|c|c|c|c|c|c|}
\hline & & & \multicolumn{7}{|c|}{ FACTORS } \\
\hline & & & \multicolumn{3}{|c|}{ Operation and function } & \multicolumn{2}{|c|}{ User and environment } & \multicolumn{2}{|c|}{ Production process } \\
\hline & & & $\begin{array}{l}\text { Operation } \\
\text { principles }\end{array}$ & $\begin{array}{c}\text { Device } \\
\text { composition }\end{array}$ & $\begin{array}{c}\text { Paintings } \\
\text { characteristics }\end{array}$ & Mode of use & $\begin{array}{c}\text { Related } \\
\text { accessories }\end{array}$ & $\begin{array}{c}\text { Materials } \\
\text { and supplies }\end{array}$ & Processes \\
\hline \multirow{10}{*}{ 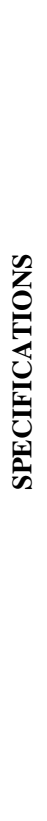 } & \multirow{4}{*}{ } & Air pressure: & Interaction & & & & & & \\
\hline & & 1 - 3.5 bar & between fluids & Inner structure & Physical & Actuator & Regulators & & \\
\hline & & $\begin{array}{l}\text { Independent } \\
\text { flows control }\end{array}$ & $\begin{array}{l}\text { Regulation } \\
\text { systems }\end{array}$ & $\begin{array}{c}\text { Actuators and } \\
\text { Regulators }\end{array}$ & $\begin{array}{l}\text { properties.: } \\
\text { —density } \\
\text { —viscosity }\end{array}$ & $\begin{array}{l}\text { position } \\
\text { and handle }\end{array}$ & $\begin{array}{l}\text { Deposits/ } \\
\text { Valves }\end{array}$ & $\begin{array}{l}\text { formats: bars, } \\
\text { sheets, } \\
\text { profiles }\end{array}$ & $\begin{array}{l}\text { manufacture } \\
\text {-Machines, } \\
\text { equipment, }\end{array}$ \\
\hline & & $\begin{array}{c}\text { Different } \\
\text { spray effects }\end{array}$ & $\begin{array}{l}\text { Atomization } \\
\text { and paint } \\
\text { spraying }\end{array}$ & $\begin{array}{c}\text { Injection } \\
\text { nozzle and exit } \\
\text { area }\end{array}$ & $\begin{array}{l}\text {-surface } \\
\text { tension }\end{array}$ & $\begin{array}{l}\text { Airbrushing } \\
\text { techniques }\end{array}$ & $\begin{array}{l}\text { Templates/ } \\
\text { Masks }\end{array}$ & $\begin{array}{l}\text {-Commercial } \\
\text { items } \\
\text { —Process }\end{array}$ & $\begin{array}{l}\text { facilities } \\
\text {-Sequence } \\
\text { of tasks and }\end{array}$ \\
\hline & \multirow{3}{*}{ 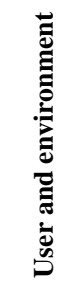 } & User adaptation & & $\begin{array}{c}\text { Body and } \\
\text { exterior handle }\end{array}$ & & $\begin{array}{l}\text { System } \\
\text { handgrip }\end{array}$ & Gloves & consumables & operations \\
\hline & & $\begin{array}{l}\text { Resistance to } \\
\text { corrosive liquids }\end{array}$ & $\begin{array}{l}\text { —Physico- } \\
\text { chemical }\end{array}$ & & $\begin{array}{l}\text { Types: } \\
\text {-inks, }\end{array}$ & $\begin{array}{c}\text { Paint } \\
\text { treatment }\end{array}$ & $\begin{array}{l}\text { Cleaning } \\
\text { Agents }\end{array}$ & $\begin{array}{l}\text { Bases and } \\
\text { coatings }\end{array}$ & \\
\hline & & $\begin{array}{l}\text { Easy cleaning } \\
\text { and maintenance }\end{array}$ & $\begin{array}{l}\text { degradation } \\
\text {-Sealing }\end{array}$ & $\begin{array}{l}\text { Exploded } \\
\text { View of } \\
\text { device }\end{array}$ & $\begin{array}{l}\text { - varnishes, } \\
\text { - aniline, } \\
\text { — lacquers ... }\end{array}$ & $\begin{array}{l}\text { Cleaning } \\
\text { Process }\end{array}$ & $\begin{array}{c}\text { Quick } \\
\text { Connects }\end{array}$ & & $\begin{array}{l}\text { Detachable } \\
\text { joints }\end{array}$ \\
\hline & \multirow{3}{*}{ 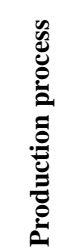 } & Fine tolerances & \multirow{3}{*}{$\begin{array}{l}\text { Properties } \\
\text { of materials } \\
\text { applied }\end{array}$} & \multirow[t]{2}{*}{ Pieces critical } & & & & $\begin{array}{l}\text { Control } \\
\text { Patterns }\end{array}$ & $\begin{array}{l}\text { Inspection } \\
\text { and } \\
\text { monitoring }\end{array}$ \\
\hline & & $\begin{array}{c}\text { High surface } \\
\text { quality }\end{array}$ & & & & $\begin{array}{l}\text { Contact } \\
\text { Zones }\end{array}$ & $\begin{array}{c}\text { Hoses } \\
\text { and fittings }\end{array}$ & Coatings & $\begin{array}{l}\text { Surface } \\
\text { finishing }\end{array}$ \\
\hline & & Sustainability & & $\begin{array}{l}\text { Total number } \\
\text { of pieces }\end{array}$ & & & & Material mass & $\begin{array}{c}\text { Energy } \\
\text { consumption }\end{array}$ \\
\hline
\end{tabular}




\section{Approach 2: Projects with derived specifications}

In this section, the cases of two design projects where the specifications are not established a priori, but are obtained from the study of factors are presented. They have been called, respectively, case 3: Urban fitness machine and case 4: Organizing bathroom furniture.

\section{Case 3: Urban fitness machine}

In this case, the project design has focused on a machine to exercise the legs and aims to propose concepts to achieve an improvement or innovation of the existing machine. Such machines can offer similar features as indoor gyms, with the distinction of offering the user a natural environment and wider schedule freedom.

The initial tasks of the project were developed according to the scheme shown in Figure 5. Firstly, the factors involved in the design of such machines were identified. As in the previously presented cases, the factors were grouped into three main blocks and were organized by columns in a matrix (Table 3). Within the operation and function block, the operating principles subgroup includes factors related to the movement, the drive, the regulation and the mechanical system strength. The type of user, exercising muscle areas and the work position are the factors included into the mode of use subgroup defined in the user and environment block.

The preliminary study of the factors included in each column of the matrix allows defining the critical design specifications, which must always be present in the new machine concepts. These specifications are shown in the last row of the matrix in Table 3.

Once the preliminary study has been achieved, three different concepts of improvement or innovation were generated:

- Concept 1: Harmony with nature.

- Concept 2: Control of the applied load.

- Concept 3: Versatility in the exercises.

Particular or desired specifications were derived from each of these concepts. Curves form, comfort and colour set were the desired specifications for the Concept 1 , focused on achieving harmony with the environment.

The proposed concepts and derived specifications were incorporated into the matrix (Table 3). This matrix synthesizes the information related to the project and promotes the reflection to develop the most appropriate concepts.

Case 4: Organizing bathroom furniture

In this case, new forms of distribution of the available space in the bathroom and organization of the different goods that are stored inside are sought. The furniture that accompanies the sink is taken as reference in order to find creative and alternative solutions to existing ones.

According to the scheme shown in Figure 5, the first task of the project was to identify the design factors on which the innovative proposals can be based. This task requires the analysis of the proposed problem and the orderly compilation of the analysed factors, which is shown in Table 4. The general specifications of the product, obtained from the review of the factors, are synthetically expressed in the last row of the matrix. E.g, the durability specification is derived from the analysis of the characteristics of the environmental and hygiene conditions, the characteristics of the available spaces and the ambient within user and environment block.

In this project, three different concepts were generated:

- Concept 1: Furniture-complete bathroom.

- Concept 2: Storage of electrical appliances.

- Concept 3: Mobile cabinet-wardrobe.

Particular specifications were derived from each of these concepts as shown in Table 4. These desired specifications mark the difference between the new design and the existing in the market.

Concept 1 is intended to integrate different bathroom components (sink, toilet and shower) into a single piece of furniture. This allows reducing the plumbing installation and to introduce a system for the toilet cistern to store and recycle grey water from the sink. The concept 2 aims to improve the storage of various electrical appliances used at the bathroom using a watertight compartment, with a base of multiple connectors and an electric cables collection system. Finally, the concept 3 focuses on facilitating the storage and classification of dirty clothes generally left in the bathroom waiting to be washed. The design of a mobile module, with multiple internal compartments with an upper part ready to be used as a temporary seat is proposed.

As in the previous case study, the matrix created out of factors, specifications and concepts is the synthesis of the initial stages of the project and aims to provide integrated information analysis. 
Table 3. SFM of the project design of urban fitness machine.

\begin{tabular}{|c|c|c|c|c|c|c|c|c|}
\hline \multicolumn{7}{|c|}{ FACTORS } & \multirow[b]{3}{*}{ Concepts } & \multirow[b]{3}{*}{$\begin{array}{c}\text { Particular } \\
\text { specifications }\end{array}$} \\
\hline \multicolumn{2}{|c|}{ Operation and function } & \multicolumn{3}{|c|}{ User and environment } & \multicolumn{2}{|c|}{ Production process } & & \\
\hline $\begin{array}{l}\text { Operation } \\
\text { principles }\end{array}$ & $\begin{array}{c}\text { Device } \\
\text { composition }\end{array}$ & Mode of use & $\begin{array}{c}\text { Related } \\
\text { accessories }\end{array}$ & $\begin{array}{l}\text { Environmental } \\
\text { characteristics }\end{array}$ & $\begin{array}{c}\text { Materials } \\
\text { and supplies }\end{array}$ & Processes & & \\
\hline $\begin{array}{l}\text {-Behaviour } \\
\text { to mechanical } \\
\text { loads } \\
\text {-Kinematics } \\
\text { of the system: } \\
\text { constraints } \\
\text { and degrees } \\
\text { of freedom } \\
\text { - Methods of } \\
\text { actuation and } \\
\text { control } \\
\text { system }\end{array}$ & $\begin{array}{l}\text { - Main parts: } \\
\text { —-structure } \\
\text { —-seat } \\
\text { —-backup } \\
\text { —Armrest } \\
\text { - Headrest } \\
\text { - Type and } \\
\text { characteristics } \\
\text { of joining } \\
\text { methods } \\
\text { —Shapes and } \\
\text { sizes of parts }\end{array}$ & $\begin{array}{l}\text { —Age and } \\
\text { physical } \\
\text { condition of } \\
\text { potential users } \\
\text { —-Areas of } \\
\text { exercised } \\
\text { muscle } \\
\text { —-Position of } \\
\text { the user when } \\
\text { performing } \\
\text { exercises } \\
\text {-Contact } \\
\text { between user } \\
\text { and machine }\end{array}$ & $\begin{array}{l}\text { —Guards } \\
\text { and security } \\
\text { features } \\
\text { —Fixations } \\
\text { on the floor } \\
\text { — Grips } \\
\text { —-Informatio } \\
\text { n panels and } \\
\text { indicators } \\
\text { of use }\end{array}$ & $\begin{array}{l}\text { —Environment } \\
\text { al conditions } \\
\text { (temperature, } \\
\text { humidity, } \\
\text { wind ...) } \\
\text { —Aesthetics } \\
\text { of the } \\
\text { environment } \\
\text { —Emotional } \\
\text { elements } \\
\text { —Misuse and } \\
\text { vandalism }\end{array}$ & $\begin{array}{l}\text {-Type and } \\
\text { format of } \\
\text { raw } \\
\text { materials } \\
\text { and materials } \\
\text {-Standardize } \\
\text { d elements } \\
\text { —Adhesives, } \\
\text { paints, } \\
\text { finishes } \\
\text { - Quantities } \\
\text { and units of } \\
\text { acquisition }\end{array}$ & $\begin{array}{l}\text { —Methods of } \\
\text { manufacturing } \\
\text { —Operations } \\
\text { process } \\
\text { —Machinery } \\
\text { and } \\
\text { equipment } \\
\text { used } \\
\text { —Control of } \\
\text { tasks and } \\
\text { materials } \\
\text { —Assembly } \\
\text { and finishing } \\
\text { product }\end{array}$ & $\begin{array}{c}\text { Concept } 2 \\
\text { Load } \\
\text { control } \\
\\
\text { Concept } 3 \\
\text { Versatility }\end{array}$ & $\begin{array}{l}\text { —Mechanism } \\
\text { weight } \\
\text { regulation } \\
\text { —-Reclining } \\
\text { back } \\
\text { — Exercises } \\
\text { in another } \\
\text { position }\end{array}$ \\
\hline \multicolumn{9}{|c|}{ General specifications } \\
\hline $\begin{array}{l}\text { Mechanical } \\
\text { strength }\end{array}$ & Hard removal & Ergonomic set & Security & Durability & Standardization & $\begin{array}{l}\text { Technical } \\
\text { feasibility }\end{array}$ & & \\
\hline
\end{tabular}

Table 4. SFM of the project design of bathroom cabinet organizer.

\begin{tabular}{|c|c|c|c|c|c|c|c|c|}
\hline \multicolumn{7}{|c|}{ FACTORS } & \multirow[b]{3}{*}{ Concepts } & \multirow[b]{3}{*}{$\begin{array}{c}\text { Particular } \\
\text { specifications }\end{array}$} \\
\hline \multicolumn{2}{|c|}{ Operation and function } & \multicolumn{3}{|c|}{ User and environment } & \multicolumn{2}{|c|}{ Production process } & & \\
\hline $\begin{array}{l}\text { Operation } \\
\text { principles }\end{array}$ & Composition & Mode of use & $\begin{array}{c}\text { Related } \\
\text { accessories }\end{array}$ & $\begin{array}{l}\text { Environmental } \\
\text { characteristics }\end{array}$ & $\begin{array}{l}\text { Materials } \\
\text { and supplies }\end{array}$ & Processes & & \\
\hline $\begin{array}{l}\text { —-Storage } \\
\text { systems } \\
\text {-Methods of } \\
\text { classification } \\
\text { of goods } \\
\text { —-Distribution } \\
\text { of space and } \\
\text { access to } \\
\text { compartments } \\
\text { —-Structural } \\
\text { strength and } \\
\text { potential user } \\
\text { charges }\end{array}$ & $\begin{array}{l}\text {-Main parts: } \\
\text { —Structure } \\
\text { —-Internal } \\
\text { divisions } \\
\text { —Fronts (set } \\
\text { and drawers) } \\
\text { - Type and } \\
\text { characteristics } \\
\text { of joining } \\
\text { methods } \\
\text { —Aesthetics } \\
\text {-Coatings }\end{array}$ & $\begin{array}{l}\text {-People: } \\
\text { —Time } \\
\text { —Parts/ } \\
\text { areas used } \\
\text { —-Instruction } \\
\text { for use } \\
\text {-Adaptation } \\
\text { to forms } \\
\text { and human } \\
\text { dimensions } \\
\text {-Minimum } \\
\text { standard } \\
\text { spaces }\end{array}$ & $\begin{array}{l}\text {-Fixings: } \\
\text {-Ground } \\
\text {-Wall } \\
\text { - Supports } \\
\text { - Handles or } \\
\text { propellants } \\
\text {-Elements } \\
\text { of internal } \\
\text { organization }\end{array}$ & $\begin{array}{l}\text { —Physical } \\
\text { variables: } \\
\text { - temperature } \\
\text {-moisture } \\
\text { —-vapours } \\
\text { —concentration } \\
\text {-Confined } \\
\text { spaces } \\
\text {-Terms of } \\
\text { hygiene } \\
\text {-Elements } \\
\text { for relaxation }\end{array}$ & $\begin{array}{l}\text {-Type and } \\
\text { format of raw } \\
\text { materials and } \\
\text { materials } \\
\text { —-Standardized } \\
\text { elements } \\
\text { —Adhesives, } \\
\text { paints, finishes } \\
\text {-Quantities } \\
\text { and units of } \\
\text { acquisition }\end{array}$ & $\begin{array}{l}\text { —Methods of } \\
\text { manufacturing } \\
\text { —Operations } \\
\text { process } \\
\text { —Machinery } \\
\text { and equipment } \\
\text { used } \\
\text { —Control of } \\
\text { tasks and } \\
\text { materials } \\
\text { —Assembly } \\
\text { and finishing } \\
\text { product }\end{array}$ & $\begin{array}{c}\text { Concept } 2 \\
\text { Storage of } \\
\text { electrical } \\
\text { appliances } \\
\\
\text { Concept } 3 \\
\text { Mobile } \\
\text { cabinet-ward } \\
\text { robe }\end{array}$ & $\begin{array}{l}\text { —Integration } \\
\text { of health } \\
\text { —Plumbing } \\
\text { reduced } \\
\text { _-Water } \\
\text { recycling } \\
\text { —Sealing } \\
\text { —-Multiple } \\
\text { plugs } \\
\text { —Wire } \\
\text { collection } \\
\text { system } \\
\text { —Classificatio } \\
\text { n of clothing } \\
\text { - Mobility } \\
\text { —Seat }\end{array}$ \\
\hline \multicolumn{9}{|c|}{ General specifications } \\
\hline $\begin{array}{l}\text { Organization } \\
\text { and resistance }\end{array}$ & $\begin{array}{l}\text { Easy assembly } \\
\text { and installation }\end{array}$ & $\begin{array}{l}\text { Ergonomic } \\
\text { and compact } \\
\text { set }\end{array}$ & $\begin{array}{l}\text { Accessibility } \\
\text { and } \\
\text { equipment }\end{array}$ & $\begin{array}{c}\text { Harmony } \\
\text { and durability }\end{array}$ & $\begin{array}{l}\text { Simplicity and } \\
\text { standardization }\end{array}$ & $\begin{array}{l}\text { Technical } \\
\text { feasibility }\end{array}$ & & \\
\hline
\end{tabular}

\section{SFM Tool Compare Analysis}

The realization of the SFM in the case studies presented provides a clear and accurate picture of the elements involved in the early stages of the product design. In the case of projects with specifications imposed, the SFM 
tool organizes the design factors establishing connections with each of the known specifications. In the case of projects with derived specifications, SFM synthesizes product requirements after the investigation of the factors affecting its design. In both cases, the aim is to obtain an overview of the factors involved in the product design, prior to the generation of conceptual alternatives and their selection. To note that the matrices remain open to the incorporation of factors not considered or specifications not listed, which can be obtained after a new review and analysis of the design process.

The development of the matrix requires understanding of the objectives proposed in the project, entails identifying of specifications, factors and design concepts and making the proper synthesis and information organization that the design team has obtained from the initial analysis of the problem. Its use as a design support tool is proposed as complementary to others that are usually employed applying the matrices.

The designer has several tools to aid decision making. Among them, the hierarchies analysis proposed by Saaty or the method developed by Pugh [31] [32]. These tools allow the assessment of different alternatives and the selection of the best valued using appropriate design criteria. In the analysis of hierarchies of Saaty the relative importance of each criterion is defined on a square matrix called "matrix of comparisons". On the other hand, Pugh's method provides an overview of advantages and disadvantages of different design alternatives through a matrix where each column represents an alternative and each row an evaluation criteria.

Several tools assist the designer when defining minimum requirements for a product, identifying opportunities for improvement and user preferences. The Kano model or the conjoint analysis technique can be included in this type of tools [33]-[35]. The use of matrices is also observed to classify the information handled along the application of these tools. The matrix that organizes functional and dysfunctional requirements is used within the Kano model and the design matrix formed by the attributes and their levels of evaluation is configured within the conjoint analysis technique.

In other cases, the design support tools are mainly used to develop solutions or generate concepts. This is the case of the TRIZ methodology based on the assumption that the principles of creativity can be applied to obtain technical innovations [36] [37]. From the "principle of contradiction" a matrix that provides a number of recommendations to solve a problem can be developed. Altshuller matrix is composed by characteristics that improve an alternative design, distributed in rows, and by characteristics that worsen it, organized in columns. The principles to resolve the contradiction are established at the intersection of rows and columns.

In most of the considered tools, the authors turn to organize the information used in their methodology in a matrix, as shown in a summarized way in Figure 6. In this paper, the organizational matrix of specifications and factors is used. Based on the work of the synthesis made by the designers in the presented cases, SFM provides a comprehensive view of the problem to be solved.

It is a tool implemented recently in the academic field related to the authors, specifically in the Industrial Design and Product Development Engineering Degree. SFM affects the early stages of product design process and reinforces the analysis and synthesis competencies. It also aims to encourage the designer reflection process when obtaining and selecting the most appropriate design concepts. Its effectiveness in this regard will be investigated in a future work.
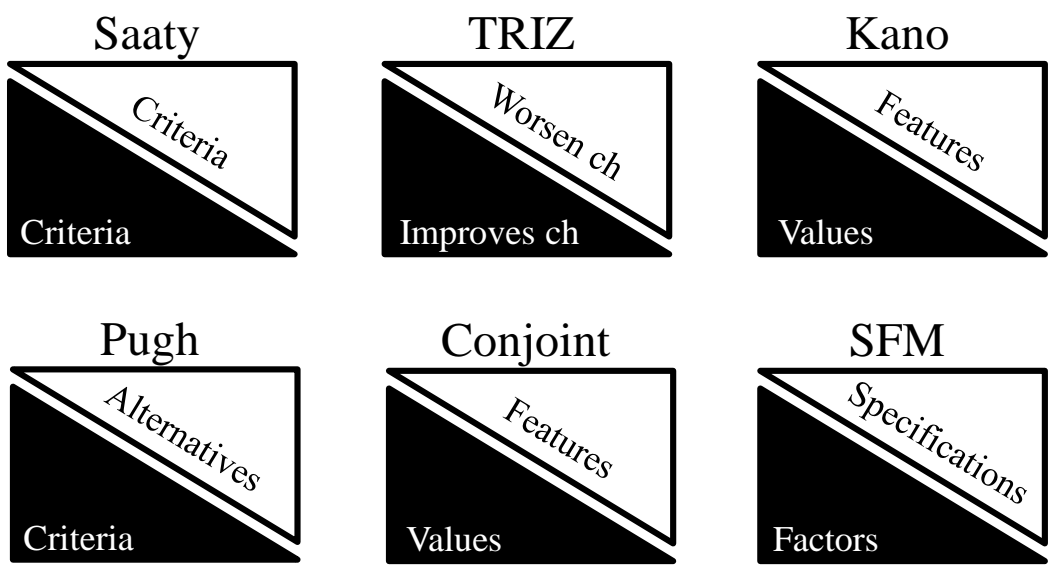

Figure 6. Aspects related in different design support tools. 


\section{Conclusions}

The early stages in the product design process play a decisive role, since it is when specifications are established, factors are identified and design concepts are defined. Two main approaches of design project development are proposed in this work, denominated respectively: projects with imposed specifications, if they are established a priori, or projects with derived specifications, if specifications are obtained from factors analysis and the generated concepts. Several cases related to the design of different product are presented to exemplify these approaches.

The development of matrices relating specifications and design factors (SFM) has been carried out for each studied case. The information structured through the matrix allows a comprehensive and integrated analysis of the problem. Its use as a design support tool is proposed as complementary to others that are already routinely used in the product design process in capturing user needs, concept generation and selection of alternatives. In each case study, the matrix increases the competences of analysis and synthesis and aims to encourage the reflection process when obtaining and selecting design concepts that are able to meet the current high standards of quality and competitiveness.

\section{References}

[1] Munari, B. (1983) ¿Cómo nacen los objetos? Apuntes para una metodología proyectual. Gustavo Gili, S.A., Barcelona.

[2] Cross, N. (1984) Developments in Design Methodology. John Wiley \& Sons Ltd., Chichester.

[3] Ulrich, K. and Eppinger, S. (2000) Product Design and Development. Irwin McGraw-Hill, Boston.

[4] Barba, E. (1993) Excelencia en el proceso de desarrollo de nuevos productos. EADA Gestión, Barcelona.

[5] Patrick, J., (1997). How to develop successful new products. Chicago: NTC Business Books.

[6] Maldonado, T. (1993) El Diseño Industrial Reconsiderado. 2 Edition, Gustavo Gili, S.A., Barcelona.

[7] Liu, S. and Boyle, I.M. (2009) Engineering Design: Perspectives, Challenges and Recent Advances. Journal of Engineering Design, 20, 7-19. http://dx.doi.org/10.1080/09544820802670914

[8] Coelho, D.A. (2011) Industrial Design—New Frontiers. InTech, Rijeka. http://dx.doi.org/10.5772/849

[9] Dorst, K. and Dijkhuis, J. (1995) Comparing Paradigms for Describing Design Activity. Design Studies, 16, $261-274$.

[10] Roozenburg, N.F.M. and Eekels, J. (1995) Product Design: Fundamental and Methods. 2 Edition, John Wiley\& Sons Ltd., Chichester.

[11] Julián, F., Orús, X.E., Pujades, N.V. and Picas, J.T. (2002) Metodología del Diseño, Historia y Nuevas Tendencias. Proceedings of VI International Congress on Project Engineering, Barcelona, 23-25 October 2002, 386-394.

[12] Ramírez, R. (2012) Guía de Buenas Prácticas de Diseño. Herramientas para la gestión del diseño y desarrollo de productos. Instituto Nacional de Tecnología Industrial-INTI, San Martín.

[13] Milton, A. and Rodgers, P. (2013) Research Methods for Product Design. Laurence King Publishing Ltd., London.

[14] Lewis, W.P. and Bonollo, E. (2002) An Analysis of Professional Skills in Design: Implications for Education and Research. Design Studies, 23, 385-406. http://dx.doi.org/10.1016/S0142-694X(02)00003-0

[15] Yang, M.Y., You, M. and Chen, F.C. (2005) Competences and Qualifications for Industrial Design Jobs: Implications for Design Practice, Education and Student Career Guidance. Design Studies, 26, 155-189. http://dx.doi.org/10.1016/j.destud.2004.09.003

[16] Bronet, F., Eglash, R., Gabriele, G., Hess, D. and Kagan, L. (2003) Product Design and Innovation: Evolution of an Interdisciplinary Design Curriculum. International Journal of Engineering Education, 19, 183-191.

[17] Findelli, A. (2001) Rethinking Design Education for the 21st Century: Theoretical, Methodological and Ethical Discussion. MIT Press, Cleveland.

[18] Winkelmann, C. and Hacker, W. (2010) Question-Answering-Technique to Support Freshman and Senior Engineers in Processes of Engineering Design. International Journal of Technology and Design Education, 20, 305-315. http://dx.doi.org/10.1007/s10798-009-9086-8

[19] Björklund, T.A. (2013) Initial Mental Representations of Design Problems: Differences between Experts and Novices. Design Studies, 34, 135-160. http://dx.doi.org/10.1016/j.destud.2012.08.005

[20] Serrano, A., Hernández, M., Pérez, E., Biel, P., Rodrigo, C., Gambau, L. and Gracia, R. (2013) Desarrollo de la competencia de síntesis en los trabajos de módulo del grado en ingeniería de diseño industrial y desarrollo de producto. IV Congreso Internacional UNIVEST, Girona.

[21] Santolaya, J.L. and Serrano, A. (2013) Análisis integrado de especificaciones y factores en la realización de proyectos 
de diseño. IV Congreso Latinoamericano de Enseñanza del Diseño, Buenos Aires.

[22] Björnfot, A. and Stehn, L. (2007) A Design Structural Matrix Approach Displaying Structural and Assembly Requirements in Construction: A Timber Case Study. Journal of Engineering Design, 18, 113-124. http://dx.doi.org/10.1080/09544820600664721

[23] Deubzer, F. and Lindermann, U. (2008) Functional Modelling for Design Synthesis Using MDM Methodology. 10th International Design Structure Matrix Conference, Stockholm, 11-12 November 2008, 403-411.

[24] Dorst, K. (2006) Design Problems and Design Pardoxes. MIT Press, Cambridge MA.

[25] Pahl, G., Beitz, W., Feldhusen, J. and Grote, K.H. (2007) Engineering Design: A Systematic Approach. 3rd Edition, Springer-Verlag London Limited, London. http://dx.doi.org/10.1007/978-1-84628-319-2

[26] Manchado, E. (2013) Diseño y aplicación de sistemas de retículas en la realización de proyectos de desarrollo de producto. Doctoral Tesis, Universidad de Zaragoza, Zaragoza.

[27] Pérez, C. (2008) La Función como Principio del Diseño. Pereira.

[28] Page, A., Porcar, R., Duch, M.J., Solaz, J. and Solaz, V. (2001) Nuevas técnicas para el desarrollo de productos innovadores orientados al usuario. Instituto de Biomecánica de Valencia, Valencia.

[29] Otto, K. and Wood, K. (2001) Product Design Techniques in Reverse Engineering and New Product Development. Prentice Hall, Upper Saddle River.

[30] Boothroyd, G., Dewhurst, P. and Knight, W.A. (2011) Product Design for Manufacture and Assembly. 3rd Edition, CRC Press, Boca Raton.

[31] Saaty, T. (1982) How to Structure and Make Choices in Complex Problems. Human Systems Management, 3, $255-261$.

[32] Pugh, S. (1990) Total Design. Integrated Methods for Successful Product Engineering. Addison-Wesley Pub. Co., Wokingham.

[33] Gustafsson, A., Ekdahl, F. and Bergmann, B. (1999) Conjoint Analysis: A Useful Tool in the Design Process. Total Quality Management, 10, 327-343. http://dx.doi.org/10.1080/0954412997866

[34] Kano, S. (2001) Life Cycle and Creation of Attractive Quality. Proceedings of the 4th International Quality Management and Organisational Development Conference, Linköping, 12-14 September 2001, 18-36.

[35] Lone, G. and Sanjeev, S. (2007) Application of Conjoint Analysis in Product Design. International Journal of Industrial Engineering: Theory Applications and Practice, 14, 141-150.

[36] Altshuller, G. and Shulyak, L. (1998) 40 Principles: TRIZ Keys to Technical Innovation. Technical Innovation Center, Worcester MA.

[37] Li, M., Ming, X.G., Zheng, M.K., Xu, Z.T. and He, L.N. (2013) A Framework of Product Innovative Design Process Based on TRIZ and Patent Circumvention. Journal of Engineering Design, 24, 830-848. http://dx.doi.org/10.1080/09544828.2013.856388 